\title{
PENGARUH TAHU STATUS HIV TERHADAP PENGGUNAAN KONDOM KONSISTEN PADA LELAKI YANG SEKS DENGAN LELAKI DI YOGYAKARTA DAN MAKASSAR (ANALISIS DATA SURVEILANS TERPADU BIOLOGI DAN PERILAKU TAHUN 2013)
}

\author{
Ririn Febriana Anggraeni' ${ }^{1}$, Pandu Riono ${ }^{2}$, M. Noor Farid ${ }^{3}$ \\ Kelompok Studi Kesehatan Reproduksi, Fakultas Kesehatan Masyarakat, Universitas Indonesia \\ ririnfebriana90@gmail.com
}

\section{INFO ARTIKEL}

Riwayat Artikel:

Diterima: 13-01-2018

Disetujui: 30-01-2018

\section{Kata Kunci: \\ LSL, \\ HIV, \\ Condom, \\ Consistency,}

\begin{abstract}
ABSTRAK
Abstrak: Hubungan seks yang berisiko menularkan HIV adalah hubungan seks dengan banyak pasangan dan berganti-ganti pasangan yang sebagian besar didominasi dengan hubungan seks komersial, baik pada kelompok heteroseksual maupun pada kelompok homoseksual atau sejenis. Kelompok yang paling berisiko tertular HIV adalah kelompok homoseksual dan biseksual yang biasa dikategorikan sebagai lelaki seks lelaki atau disebut LSL. Di banyak bagian wilayah, HIV di kalangan LSL muncul dengan penularan HIV yang sangat cepat. Penelitian ini bertujuan untuk mengetahui pengaruh tahu status HIV terhadap penggunaan kondom konsisten pada LSL di Yogyakarta dan Makassar dan melihat adakah perbedaan hasil analisis dengan menggunakan metode RDS dan non RDS terhadap indikator program. Penelitian ini menggunakan data STBP 2013. Dari hasil analisis diperoleh bahwa di Yogyakarta ada pengaruh tahu status HIV terhadap penggunaan kondom konsisten dengan $O R$ sebesar 6,6 dan 95\% Cl 2,1-20,9, sedangkan di Makassar belum dapat diketahui pengaruh tahu status HIV dengan penggunaan kondom konsisten dengan OR sebesar 1,6 dan 95\% Cl 0,6 - 4,4. Ada perbedaan hasil analisis dengan menggunakan metode RDS dan non RDS terhadap indikator program. Terdapat pengaruh tahu status HIV dengan penggunaan kondom konsisten pada lelaki yang seks dengan lelaki di Yogyakarta sedangkan di Makassar belum dapat diketahui pengaruh tahu status HIV dengan penggunaan kondom konsisten. Terdapat perbedaan hasil analisis dengan menggunakan metode RDS dan non RDS terhadap indikator program.
\end{abstract}

\begin{abstract}
Sex which higher risk of spreading HIV is sex with multiple partners and change partners that is largely dominated by commercial sex, either on the heterosexual and homosexual group, or similar sexual behaviour. Groups most at risk of contracting HIV is a group of homosexual and bisexual men are commonly categorized as men sex with men, or so-called MSM. In many parts of the region, HIV among MSM appears with HIV infection very quickly. This study aimed to determine the effect knowing their HIV status toward consistency condom use in MSM in Yogyakarta and Makassar and to see the differences between analysis using RDS and non RDS to indicator of program. This study uses data IBBS 2013. From the results of the analysis showed that in Yogyakarta there was an effect Yogyakarta of knowing HIV status toward consistency condom use with an OR of 6,6 and 95\% Cl 2,1-20,9, while in Makassar is unclear knowing HIV status toward consistent condom use with an OR of 1.6 and 95\% Cl 0,6 - 4,1. There is differences between analysis using RDS and non RDS to indicator of program. There is Influence of knowing HIV Status to consistent Condom use in Yogyakarta while in Makassar unclear knowing HIV status toward consistent condom use. There is differences between analysis using RDS and non RDS to indicator of program.
\end{abstract}




\section{A. PENDAHULUAN}

Epidemi Human Immunodeficiency Virus (HIV) secara global masih menjadi masalah kesehatan masyarakat yang sangat serius. Wilayah Asia Pasifik adalah wilayah dengan jumlah terbesar orang dengan HIV selain Afrika sub-sahara. Pola penularan HIV di Asia berbeda di Afrika. Sebagian besar penularan HIV di Asia di dominasi oleh kegiatan seksual berisiko dan penggunaan jarum suntik pada pengguna narkoba suntik.

Secara umum kejadian infeksi baru HIV di wilayah Asia Selatan dan Asia Tenggara mengalami penurunan sebesar 8\% dan 16\% antara tahun 2005 dan 2013. Beberapa negara menunjukkan gambaran beragam yaitu kejadian infeksi HIV baru menurun sebesar 58\% di Myanmar, 46\% di Muangthai, 43\% di Vietnam dan 31\% di Papua Nugini. Walaupun jumlah infeksi HIV baru menurun sebesar 19\% di India, namun masih menyumbang $38 \%$ dari semua kejadian infeksi HIV baru di wilayah tersebut ${ }^{[1]}$.

Berbeda dengan situasi HIV di Indonesia, kejadian infeksi HIV baru diperkirakan meningkat dan mencapai $23 \%$ untuk kejadian infeksi HIV baru di wilayah ini pada tahun 2013. Kenyataan tersebut mengindikasikan Indonesia adalah negara kedua dengan jumlah kasus infeksi HIV baru terbanyak setelah India [1].

Perilaku seks yang berisiko menularkan HIV adalah hubungan seks dengan banyak pasangan dan berganti pasangan yang sebagian besar didominasi dengan perilaku seks komersial, baik pada perilaku seksual heteroseksual maupun pada perilaku seksual homoseksual. Perilaku seks dengan banyak pasangan merupakan faktor penting yang perlu diperhatikan. Seks komersial atau seks dengan imbalan telah menjadi sebuah faktor yang sangat penting pada penyebaran infeksi HIV, khususnya di kawasan Asia. Selain itu, hubungan seks kasual atau tanpa imbalan pun dapat berisiko tertular HIV apabila dilakukan dengan banyak pasangan seks.

Kelompok yang paling berisiko tertular HIV adalah kelompok gay dan biseksual yang biasa dikategorikan sebagai lelaki seks lelaki atau disebut LSL. Di banyak bagian wilayah di dunia, HIV pada kelompok LSL muncul dengan penularan HIV yang sangat cepat.

Data menunjukkan bahwa prevalensi HIV pada LSL meningkat di banyak negara dan kota, termasuk kota di Tiongkok, Indonesia, Filipina dan Vietnam. Prevalensi HIV pada kelompok LSL adalah antara 4-9\% di Tiongkok, India, Indonesia, Jepang, Nepal, Thailand dan Vietnam, dan 10\% atau lebih tinggi di Australia, Malaysia, Mongolia, dan Myanmar. Prevalensi HIV pada kelompok LSL lebih tinggi yaitu 24,4\% dibandingkan dengan prevalensi HIV pada penduduk di wilayah Muangthai, yaitu 7\%. Demikian pula di India, prevalensi HIV di kelompok pria gay dan LSL adalah $15 \%$, tiga kali prevalensi nasional [1].

Prevalensi HIV pada tiga kota di Indonesia yaitu Tangerang, Yogyakarta, dan Makassar, menurut Surveilans Terpadu Biologi dan Perilaku (STBP) tahun 2009 dan tahun 2013, meningkat padapengguna jarum suntik (penasun) dan lelaki yang seks dengan lelaki (LSL). Namun besar peningkatan pada LSLdari $7 \%$ (2009) menjadi 12,8\% (2013), artinya penyebaran HIV pada LSL hampir 2 kali lipat dibandingkan pada kelompok penasun, yaitu 27\% pada tahun 2009 dan 39,5\% pada tahun $2013^{[2] .}$
Seks anal merupakan jalur utama penularan HIV di kelompok LSL. Seks anal tanpa kondom berisiko tinggi karena kulit (mukosa) lapisan rektum mudah mengalami lesi yang dapat meningkatkaninfeksi HIV. Selain itu, daerah analbanyak sel kekebalan tubuh yang menjadi sasaran bagi HIV [3]

Sebagian besar sel kekebalan dalam tubuh, termasuk sel yang merupakan sasaran utama untuk HIV, terletak di selaput lendir saluran pencernaan, yang meliputi rectum [4].

Beberapa studi menunjukkan bahwa HIV dapat ditemukan dalam cairan anal seseorang yang hidup dengan HIV. Bahkan, salah satu penelitian terhadap 64 lelaki HIV positif (yang sekitar setengah dari mereka memakai ARV) ditemukan bahwa, secara keseluruhan, jumlah rata-rata virus dalam cairan anal mereka lebih tinggi dibandingkancairan semen dan darah mereka [5] Tidak adanya legalitas seperti pernikahan antara sesama jenis juga mendorong kelompok ini memiliki banyak pasangan seksual. Mereka umumnya mengaku berhubungan seks dengan banyak pasangan. LSL tidak hanya berhubungan seks dengan pasangan tetap dan pasangan kasual, tetapi juga dengan pasangan komersial LSL berhubungan seks dengan cara membeli dan menjual seks, baik pada perempuan maupun laki-laki. Jaringan seksual yang luas ini meningkatkan risiko penularan pada LSL dan pasangan seksualnya ${ }^{[2]}$.

Upaya pencegahan HIV terutama didasarkan pada upaya untuk melakukan perubahan perilaku seksual seseorang yang berisiko tertular HIV dan promosi penggunaan kondom. Promosi kondom pada LSL masih sulit dilakukan karena sulit untuk menjangkau populasi LSL [6].

Bila dibandingkan dengan STBP 2009, pada STBP 2013 penggunaan kondom dengan pasangan tidak tetap pada LSL meningkat dari $56 \%$ menjadi $68 \%$, namun masih banyak LSL yang tidak konsisten menggunakan kondom. LSL yang konsisten menggunakan kondom hanya $38 \%{ }^{[2]}$.

Padahal penggunaan kondom secara konsisten dapat mencegah terjadinya penularan infeksi menular seksual dan HIV. Penelitian [7] mengungkapkan bahwa kondom yang gencar dipromosikan di San Francisco di awal epidemi HIV menurunkan tingkat insiden untuk semua IMS secara substansial dan kejadian HIV di awal 1980an menjadi kurang dari $1 \%$ setelah tahun 1985.US National Institutes of Health dan World Health Organization (WHO) menemukan kondom pada dasarnya kedap partikel ukuran patogen penyakit menular seksual, termasuk virus. Weller (1993) mengungkapkan bahwa efektivitas kondom dalam mencegah transmisi virus dan bakteri adalah 69-94\% [8] Hal ini memperkuat pernyataan bahwa pemakaian kondom secara konsisten mampu menurunkan kejadian IMS dan transmisi HIV.

Selain peningkatan kejadian HIV pada LSL, temuan lain dari STBP 2013 ini adalah peningkatan IMS pada kelompok ini. Prevalensi sifilis meningkat dari $8 \%$ (2009) menjadi 11,3\% (2013), prevalensi gonore meningkat dari 17\% (2009) menjadi 21,2\% (2013) dan prevalensi klamidia meningkat $17 \%$ (2009) menjadi $23 \%$ (2013).

LSL yang pernah melakukan tes HIV, meskipun meningkat pada tahun 2013 (38\%) dibandingkan tahun 2007 (25\%), namun masih banyak LSL yang belum 
mengetahui status HIV dirinya dan pasangannya. Sedangkan salah satu program pemerintah dalam penanggulangan HIV adalah tes HIV dalam menjangkau populasi yang berisiko tertular HIV.

Perubahan hubungan seksual berdasarkan status HIV juga sebagian menjelaskan perbedaan antara tren HIV dan IMS lain. Tren baru dalam perilaku yang dibahas oleh para aktivis Perancis dan intelektual di bawah istilah seroadaptasi. Seroadaptasi didefinisikan sebagai perilaku seksual untuk mengurangi risiko penularan HIV dan transmisi berdasarkan mengetahui status HIV dirinya dan serostatus mitra seksual. Seroadaptasi terdiri dari perilaku seksual untuk mengurangi risiko penularan HIV dengan mengurangi jumlah pasangan dan penggunaan kondom [9].

Sebuah survei yang dilakukan pada tahun 2004 di San Francisco menemukan bahwa secara kolektif seroadaptasi adalah strategi preventif yang paling umum digunakan oleh LSL. Seroadaptasi digunakan untuk menggambarkan pola perilaku seksual untuk individu atas semua mitra mereka namun mengabaikan fakta bahwa lelaki yang terlibat dalam perilaku yang berbeda dengan mitra yang berbeda ${ }^{[10]}$.

Pada LSL penting untuk mempelajari tentang seroadaptasi dengan perilaku seks, termasuk penggunaan kondom. Studi risiko HIV harus dirancang untuk menilai perilaku seroadaptasi agar lebih informatif. Penelitian tersebut juga merupakan evaluasi yang penting apakah intervensi pemerintah terhadap kelompok ini sudah berjalan efektif ataukah belum cukup efektif untuk mengubah perilaku LSL dalam penggunaan kondom secara konsisten. Berdasarkan hal tersebut di atas, maka penulis tertarik meneliti pengaruh tahu status HIV terhadap penggunaan kondom konsisten pada LSL dengan menggunakan data STBP 2013.

\section{B. TINJAUAN TEORITIS}

Tes HIV dianggap sebagai prioritas dalam strategi untuk mencegah penyebaran HIV dan menyediakan perawatan, dukungan dan pengobatan untuk orang yang sudah hidup dengan HIV. Tes HIV yang meliputi konseling pengurangan risiko, sangat mempengaruhi persepsi seseorang merasa berisiko tertular HIV dan telah menunjukkan efek besar pada perubahan perilaku berisiko. Pengetahuan tentang status HIV terutama di antara lelaki merupakan langkah penting dalam pencegahan HIV seperti yang telah dikaitkan dengan penurunan perilaku berisiko bagi mereka yang dites positif HIV [11] . Beberapa pria mungkin memiliki alasan tertentu untuk tidak melindungi diri terhadap HIV atau tidak tes HIV untuk mengetahui status HIV mereka, tetapi ini mungkin didasarkan pada kesalahpahaman atau asumsi yang salah. Seperti contoh, LSL tidak tahu ke mana harus pergi untuk tes, berapa lama waktu yang dibutuhkan, takut penuntutan atau bahkan hanya sampai ke lokasi tes, dapat menunda orang. LSL harus didorong untuk melihat bahwa manfaat tes HIV lebih besar daripada ketidaknyamanan yang dirasakan. Sebuah penghalang umum untuk tes HIV adalah kekhawatiran tentang apakah kerahasiaan dapat dijamin, dan jika 'aman' untuk pergi ke klinik daripada dokter mereka untuk tes HIV, terutama karena permintaan uji tidakberisi rincian pasien. Pria harus dibuat sadar protokol kerahasiaan terlepas dari pengaturan tes ${ }^{[12]}$.
LSL yang meskipun sudah melakukan tes HIV, ada diantara mereka yang tidak mengambil hasil tesnya dikarenakan ketakutan akan hasil tes tersebut. Menurut Hussen, et al. (2013) yang melakukan studi kualitatif pada kelompok ini yaitu peserta tahu risiko perilaku seksual dan tahu bahwa pengujian perlu dilakukan. Dalam kasusnya, tingkat risiko yang tinggi dirasakan dan takut harus berurusan dengan hasil tes yang positif HIV, sehingga menyebabkan dia untuk menunda atau tidak mengambil hasil tesnya. Transmisi HIV didorong oleh prilaku. Teori tentang bagaimana individu mengubah perilaku mereka telah memberikan dasar bagi sebagian besar upaya pencegahan HIVdi seluruh dunia. Teori ini dibuat menggunakan kognitifsikap dan afektif-motivasi konstruksi [13].

Model pengurangan risiko AIDS, adalah dikembangkan secara khusus untuk AIDS dan dapat dikategorikan menjadi 3 kelompok besar: mereka memprediksi perilaku berisiko, mereka memprediksi perubahan perilaku dan memprediksi mereka pemeliharaan perilaku yang aman. Model perubahan perilaku individu umumnya berfokus pada tahap bahwa individu melewati sementara mencoba untuk mengubah perilaku.

Meskipun setiap teori adalah dibangun di atas asumsi yang berbeda mereka semua negara bahwa perubahan perilaku terjadi dengan mengubah situasi risiko memproduksi potensial dan hubungan sosial, persepsi risiko, sikap diri, keyakinan khasiat, niat dan hasil harapan ${ }^{[13]}$.

Sehubungan dengan HIV, intervensi sering menargetkan persepsi risiko, keyakinan keparahan AIDS ("tidak ada obat"), keyakinan efektivitas penggunaan kondom dan manfaat penggunaan kondom atau menunda timbulnya relativitas seksual sosial (atau belajar) teori premis dari kognitif sosial. Teori jaringan sosial memandang perilaku bukan sebagai fenomena individual tetapi melalui hubungan, dan menghargai bahwa perilaku berisiko HIV, seperti banyak lainnya perilaku kesehatan, secara langsung melibatkan dua orang [14].

Sehubungan dengan relativitas seksual, jaringan sosial berfokus pada kedua dampak pencampuran selektif (yaitu betapa berbedanya orang memilih dengan siapa mereka bergaul), dan variasi dalam pola kemitraan (panjang kemitraan dan tumpang tindih). Meskipun hubungan dan komunikasi dengan pasangan adalah unit terkecil dari jejaring sosial, sangat penting untuk memahami transmisi HIV model ini, ruang lingkup dan karakter jaringan sosial seseorang yang lebih luas. Orang-orang yang menjadi acuan orang lain dan yang menjadi contoh dalam berperilaku, merupakan kunci secara komprehensif dalam mengubah perilaku berisiko individu. Norma-norma sosial yang terbaik harus dapat dipahami pada tingkat jaringan sosial.

Seroadaptasi terdiri dari perilaku seksual untuk mengurangi risiko penularan HIV dengan mengurangi jumlah pasangan dan penggunaan kondom. Seroadapatasi telah ditawarkan sebagai istilah yang lebih luas untuk mencakup berbagai praktek pengurangan dampak buruk seksual berdasarkan pengetahuan sendiri dan mitra serostatus [9].

Sebuah survei yang dilakukan pada tahun 2004 di San Francisco menemukan bahwa secara kolektif seroadaptasi adalah strategi preventif yang paling umum digunakan oleh LSL. Namun seroadaptasi 
digunakan untuk menggambarkan pola perilaku seksual untuk individu atas semua mitra mereka mengabaikan fakta bahwa lelaki yang terlibat dalam perilaku yang berbeda dengan mitra yang berbeda ${ }^{[10]}$.

Praktek seks yang lebih aman termasuk seks anal dengan kondom, seks oral, dan seks selain oral atau anal seks. Strategi seroadatasi termasuk "serosorting murni" (dengan mitra seroconcordant), "serosorting oral seks" (dengan mitra seroconcordant, oral seks dengan serodiskordan atau status tidak diketahui), "serosorting kondom" (dengan mitra serodiskordan atau status tidak diketahui), "seropositioning" (dengan mitra seroconcordant, dengan serodiskordan atau status tidak diketahui, menjadi insertif dari pasangan dengan HIV negatif atau dengan pasangan serodiskordan atau status tidak diketahui), dan "seropositioning kondom" (dengan mitra seroconcordant, kondom digunakan pada pasangan dengan status HIV negatif yang menjadi posisi reseptif dengan serodiskordan atau tidak diketahui, penggunaan kondom oleh LSL HIV positif di posisi insertif dengan serodiskordan atau tidak diketahui). Risiko akuisisi tertinggi ada pada LSL yang menerima cairan semen orang dengan status HIV negatif LSL yang memiliki mitra serodiskordan atau status HIV mitra tidak diketahui. Risiko penularan tertinggi insertif dari pasangan dengan HIV positif atau dengan pasangan serodiskordan atau status tidak diketahui. Namun yang paling berisiko dibanding LSL yang berada pada posisi insertif adalah LSL dengan posisi reseptif karena menerima cairan semen dari pasangan seksnya yang HIV positif dan karena rectum mudah terjadinya lesi atau perlukaan pada mukosa rektum sehingga memudahkan transmisi HIV [12].

\section{METODE PENELITIAN}

Desain peneilitian yang digunakan dalam Survei Terpadu Biologi Perilaku (STBP) pada kelompok Lelaki yang Seks dengan Lelaki di tahun 2013 adalah cross sectional dengan metode sampel Respondent Driven Sampling. Populasi penelitian adalah lelaki suka lelaki, yaitu lelaki yang mengaku telah berhubungan seks dengan lelaki dalam satu tahun terakhir dan tinggal di kota tersebut.

Meode pengambilan sampel pada STBP kelompok LSL mengunakan metode respondent driven sampling (RDS). RDS adalah sebuah teknik sampling secara jemput bola (snowball) berdasarkan pada kuota perekrutan (yang menghindari perekrutan keseluruhan sampel dari sejumlah individu yang terbatas) dan insentif rangkap untuk memotivasi perekrut dan yang direkrut. Dalam teori, kehomogenan sampel bisa dicapai sesudah paling tidak 3 gelombang perekrutan [2].

RDS berawal dari sejumlah kecil peserta yang dipilih secara purposif yang biasanya disebut seed atau orang yang diberikan kupon pertama kali. Target seed LSL adalah sekitar 8 orang, yang seharusnya dipilih seheterogen mungkin untuk memastikan bahwa sembarang anggota kelompok kemungkinan besar untuk direkrut. Seed yang mendasari gelombang nol akan merekrut mereka yang membentuk gelombang perekrutan pertama (dan seterusnya). Seed yang direkrut adalah orang yang dapat memotivasi orang lain untuk ikut dalam program dan mereka harus mendukung tujuan dari program ini. Di samping itu seed ini diusahakan berasal dari orang dengan karakteristik yang beragam, karakteristik tersebut misalnya umur, jenis kelamin, wilayah tempat tinggal, status sosial dan ekonomi, dan sebagainya [2].

Pada awalnya dipilih sebanyak 8 seed namun bila dalam tenggat waktu survei sampel belum terpenuhi bisa ditambahkan beberapa seed lagi. Seed akan dipilih oleh staf LSM yang menyediakan pelayanan kepada kelompok sasaran. Seed tersebut seharusnya dikenal baik dan diterima luas oleh kalangan mereka atau bias disebut sociometric star. Selain itu juga diharapkan bahwa yang dipilih adalah orang yang dapat memotivasi orang lain untuk ikut dalam program dan mereka harus mendukung tujuan dari program ini [2].

Umumnya para anggota dari target populasi yang diberi kupon pertama kali akan diminta untuk merekrut 3 LSL, sehingga para seed ini akan memberikan 3 kupon untuk diberikan kepada teman-teman di komunitasnya sesama LSL yang berkenan untuk direkrut. Seed diusahakan berasal dari berbagai kelompok umur dan tinggal di wilayah yang berbeda di kota yang disurvei serta dari latar belakang sosial ekonomi yang beragam. Klinik tetap buka pada akhir pekan dan jam buka adalah dari jam 12 siang sampai dengan jam 9 malamuntuk menjamin akses kepada LSL yang bekerja [2].

Sampel yang direncanakan untuk STBP 2013 di 3 kota di Indonesia, yaitu Tangerang, Yogyakarta, dan Makassar dengan sejumlah 250 responden untuk setiap masing-masing kota.

Sampel yang digunakan dalam penelitian ini adalah sampel yang memiliki nomor kupon. Tangerang tidak memenuhi kelayakan untuk dianalisis secara RDS karena dari 251 responden hanya ada 18 data responden yang memiliki nomor kupon. Sedangkan di Yogyakarta dari 172 responden yang memiliki nomor kupon sebanyak 170 responden dan di Makassar dari 250 responden yang memiliki nomor kupon sebanyak 242 responden.

Adapun kriteria inklusi

$1 \quad$ Secara biologis lelaki

2 Penderita bertempat tinggal di wilayah survei paling kurang selama satu bulan

3 Berhubungan seks dengan lelaki dalam satu tahun terakhir

4 Bersedia menjadi responden dan diwawancarai dalam penelitian ini

Sedangkan kriteria eksklusi

1. Pria transgender

2. Tidak memiliki nomor kupon

Analisis data dilakukan dengan memperhatikan metode pengambilan sampel yang tidak random, yaitu menggunakan metode RDS. Analisis terhadap variabelvariabel yang dipakai dalam indikator program bila dibobotkan dengan menggunakan RDS dan dibandingkan bila tidak diperhatikan cara pengambilan sampelnya. Analisis data dengan memperhatikan RDS dilakukan sesuai dengan informasi dari jumlah network dan pembobotan berdasarkan jumlah network, seed, wave, dan recruiter yang nantinya agar dapat melihat proporsi pada populasi.

Langkah terakhir melakukan analisis regresi logistik dengan pembobotanRDS sekaligus melakukan adjustment dengan beberapa variabel confounder dan melaporkan asosiasi antara variabel independen dengan variabel dependen dengan nilai Adjusted OR. 


\section{HASIL DAN PEMBAHASAN}

Berikut ini adalah karakteristik, perilaku dan jenis pasangan LSL yang telah dibobotkan dengan menggunakan RDS:

TABEL 1

Karakteristik LSL di Yogyakarta dan Makassar tahun 2013

\begin{tabular}{|c|c|c|c|c|c|}
\hline \multirow[t]{2}{*}{ No. } & \multirow[t]{2}{*}{ Variabel } & \multicolumn{2}{|c|}{$\begin{array}{l}\text { Yogyakarta } \\
(n=170)\end{array}$} & \multicolumn{2}{|c|}{$\begin{array}{l}\text { Makassar } \\
(n=242)\end{array}$} \\
\hline & & $\mathrm{N}$ & $\%$ & $\mathrm{~N}$ & $\%$ \\
\hline \multirow[t]{4}{*}{1.} & $\begin{array}{l}\text { Umur pertama } \\
\text { herhuhungan seks }\end{array}$ & 36 & 180 & 66 & 275 \\
\hline & a. dibawah 15 & 88 & 47,8 & 127 & 55,5 \\
\hline & tahun & 42 & 29,2 & 34 & 10,8 \\
\hline & $\begin{array}{l}\text { b. } 15-19 \text { tahun } \\
\text { c. diatas } 19 \text { tahun } \\
\text { d. tidak menjawab }\end{array}$ & 4 & 5,0 & 15 & 4,2 \\
\hline 2. & $\begin{array}{l}\text { Sex pertama dengan } \\
\text { paksaan }\end{array}$ & 57 & 33,5 & 30 & 12,5 \\
\hline 3. & $\begin{array}{l}\text { Penggunaan kondom } \\
\text { pada seks terakhir }\end{array}$ & $\begin{array}{c}12 \\
1\end{array}$ & 71,4 & 156 & 65,3 \\
\hline 4. & $\begin{array}{l}\text { Konsistensi } \\
\text { penggunaan kondom }\end{array}$ & 81 & 37,2 & 63 & 26,3 \\
\hline 5. & $\begin{array}{l}\text { Pengetahuan } \\
\text { pencegahan HIV }\end{array}$ & 165 & 97,0 & 220 & 91,0 \\
\hline 6. & $\begin{array}{l}\text { Terpapar dengan } \\
\text { layanan pencegahan }\end{array}$ & 24 & 14,2 & 9 & 4,3 \\
\hline 7. & $\begin{array}{l}\text { Persepsi berisiko } \\
\text { tertular HIV }\end{array}$ & 121 & 71,0 & 95 & 39,0 \\
\hline
\end{tabular}

TABEL 2

Jenis Pasangan Seks pada LSL di Yogyakarta \& Makassar tahun 2013

\begin{tabular}{|c|c|c|c|c|c|}
\hline \multirow[t]{2}{*}{ No } & \multirow[t]{2}{*}{ Variabel } & \multicolumn{2}{|c|}{$\begin{array}{l}\text { Yogyakarta } \\
(n=170)\end{array}$} & \multicolumn{2}{|c|}{$\begin{array}{c}\text { Makassar } \\
(n=242)\end{array}$} \\
\hline & & $\mathrm{n}$ & $\%$ & $\mathrm{n}$ & $\%$ \\
\hline 1. & $\begin{array}{l}\text { Pasangan lelaki non } \\
\text { komersial }\end{array}$ & 146 & 86,2 & 123 & 51,0 \\
\hline 2. & $\begin{array}{l}\text { Pasangan perempuan non } \\
\text { komersial }\end{array}$ & 30 & 18,4 & 117 & 48,0 \\
\hline 3. & Pasangan waria & 1 & 0,6 & 166 & 69,0 \\
\hline 4. & $\begin{array}{l}\text { Pasangan seks komersial } \\
\text { a. Menjual seks pada } \\
\text { lelaki }\end{array}$ & 34 & 20,0 & 81 & 33,0 \\
\hline & $\begin{array}{l}\text { b. Menjual seks pada } \\
\text { wanita }\end{array}$ & 12 & 6,8 & 63 & 24,4 \\
\hline & $\begin{array}{l}\text { c. Membeli seks pada } \\
\text { lelaki }\end{array}$ & 15 & 9,4 & 11 & 4,5 \\
\hline
\end{tabular}

TABEL 3

Seks, Kondom, Pengetahuan \& Persepsi pada LSL di Yogyakarta \& Makassar tahun 2013

\begin{tabular}{|c|c|c|c|c|c|}
\hline \multirow[b]{2}{*}{ No. } & \multirow[b]{2}{*}{ Variabel } & \multicolumn{2}{|c|}{$\begin{array}{c}\text { Yogyakarta } \\
(n=170)\end{array}$} & \multicolumn{2}{|c|}{$\begin{array}{c}\text { Makassar } \\
(n=242)\end{array}$} \\
\hline & & $\mathrm{N}$ & $\%$ & $\mathrm{n}$ & $\%$ \\
\hline \multirow[t]{4}{*}{1.} & Umur & & & & \\
\hline & a. 15-19 tahun & 19 & 18,2 & 64 & 36,6 \\
\hline & b. 20-35 tahun & 139 & 74,0 & 160 & 60,0 \\
\hline & c. $>35$ tahun & 12 & 7,8 & 18 & 3,4 \\
\hline \multirow[t]{5}{*}{2.} & Pendidikan & & & & \\
\hline & a. Tidak sekolah & - & - & 1 & 1,6 \\
\hline & b. Dasar & 14 & 13,7 & 107 & 46,4 \\
\hline & c. Menengah & 85 & 49,0 & 116 & 48,0 \\
\hline & d. Atas & 71 & 37,3 & 18 & 4,0 \\
\hline \multirow[t]{3}{*}{3.} & Pekerjaan & & & & \\
\hline & a. Bekerja & 39 & 16,6 & 92 & 32,2 \\
\hline & b. Tidak Bekerja & 131 & 83,4 & 150 & 67,8 \\
\hline \multirow[t]{4}{*}{4.} & Status perkawinan & & & & \\
\hline & a. Lajang & 155 & 91,0 & 172 & 66,5 \\
\hline & b. Menikah & 14 & 8,2 & 58 & 30,5 \\
\hline & $\begin{array}{ll}\text { c. } & \text { Cerai } \\
\text { mati/hidup }\end{array}$ & 1 & 0,8 & 12 & 3,0 \\
\hline \multirow[t]{3}{*}{5.} & $\begin{array}{l}\text { Jumlah Pasangan } \\
\text { seks }\end{array}$ & & & & \\
\hline & a. $=<2$ orang & 130 & 84,3 & 164 & 63,2 \\
\hline & b. >2 orang & 40 & 15,7 & 78 & 36,8 \\
\hline
\end{tabular}

Dari tabel 1, 2, dan 3 dapat dilihat umur LSL yang terbanyak di Yogyakarta dan Makasaar ada pada kelompok umur 20-35 tahun. LSL di Yogyakarta mayoritas adalah LSL dengan pendidikan menengah dan atas, sedangkan mayoritas LSL di Makassar berpendidikan dasar dan menengah. Sebagian besar LSL baik di Yogyakarta maupun di Makassar memiliki pendapatan dari hasil bekerja. LSL yang menikah lebih banyak ditemui di Makassar dibandingkan dengan LSL di Yogyakarta. Jumlah pasangan seks terbanyak adalah $\leq 2$ orang baik pada LSL di Yogyakarta maupun LSL di Makassar.

Pada saat pertama berhubungan seksual, paling banyak LSL ini mengaku tidak melakukannya dengan terpaksa. Penggunaan kondom seks terakhir maupun sebulan terakhir secara konsisten baik pada bukan seks komersial maupun seks komersial di Yogyakarta masih rendah dibandingkan di Makassar. Pengetahuan LSL di Yogyakarta dan Makassar tentang cara pencegahan HIV dengan menggunakan kondom dan mengurangi jumlah pasangan seks adalah baik.

Dalam setahun terakhir LSL yang pernah terjangkau oleh layanan pencegahan seperti pernah menghadiri pertemuan atau berdiskusi dengan petugas layanan mengenai pencegahan penularan HIV dan IMS, terpapar informasi tentang pencegahan penularan HIV dan IMS baik melalui media cetak maupun media elektronik, baik di Yogyakarta maupun Makassar masih rendah.

LSL yang merasa berisiko tertular HIV lebih banyak di Yogyakarta dibandingkan di Makassar dan diantara LSL di Yogyakarta yang pernah mengalami gejala IMS setahun terakhir sebagian besar pernah berobat ke layanan kesehatan. 
Indikator Program Berdasarkan Analisis RDS dan Non RDS

Sesuai dengan tujuan penelitian ini, data diolah dan dianalisis dengan cara RDS dan Non RDS untuk melihat ada atau tidak ada perbedaan hasil dari data yang diolah dan dianalisis dengan cara RDS dan Non RDS. Analisis secara RDS dapat menghitungkan proporsi pada sampel dan proporsi pada populasi. Lihat tabel 4 adalah proporsi data yang diolah menggunakan RDS dan Non RDS kemudian dibandingkan dengan hasil laporan STBP 2013.

TABEL 4

Prevalensi HIV, IMS, Tes HIV dan Tahu status HIV pada LSL di Yogyakarta tahun 2013

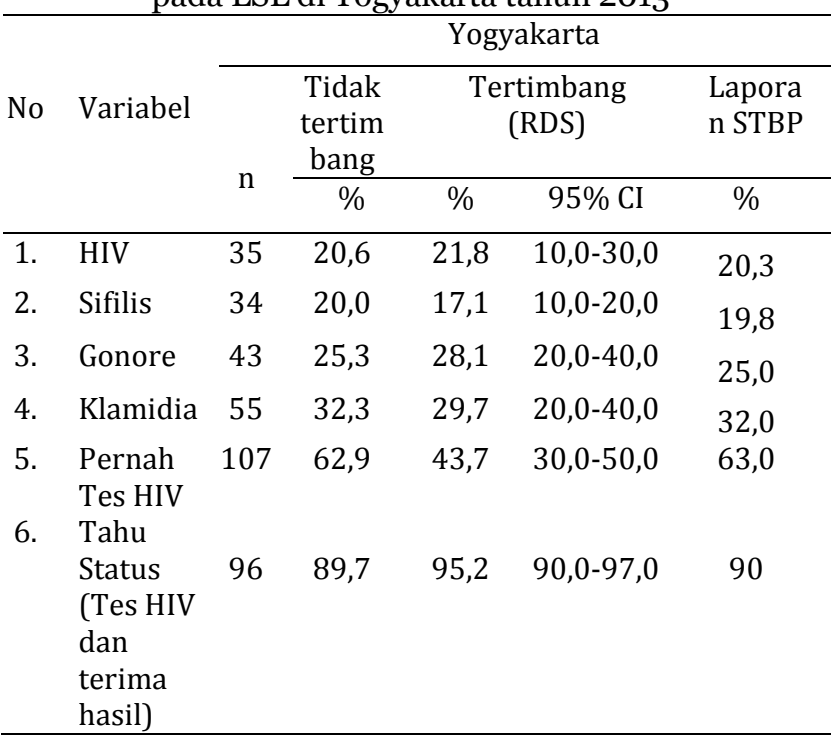

TABEL 5

Prevalensi HIV, IMS, Tes HIV dan Tahu status HIV pada LSL di Makassar tahun 2013

\begin{tabular}{|c|c|c|c|c|c|c|}
\hline \multirow{3}{*}{ No } & \multirow{3}{*}{ Variabel } & \multicolumn{5}{|c|}{ Makassar } \\
\hline & & \multirow{2}{*}{$\mathrm{n}$} & $\begin{array}{c}\text { Tidak } \\
\text { tertimbang }\end{array}$ & \multicolumn{2}{|c|}{$\begin{array}{l}\text { Tertimbang } \\
\text { (RDS) }\end{array}$} & \multirow{2}{*}{$\begin{array}{c}\text { Laporan } \\
\text { STBP } \\
\%\end{array}$} \\
\hline & & & $\%$ & $\%$ & $95 \%$ CI & \\
\hline 1. & HIV & 4 & 1,6 & 1,0 & $0-2,0$ & 1.6 \\
\hline 2. & Sifilis & 5 & 2,1 & 1,3 & $0-2,0$ & 2,4 \\
\hline 3. & Gonore & 17 & 7,0 & 3,8 & $1,0-5,0$ & 6,8 \\
\hline 4. & Klamidia & 18 & 7,4 & 4,4 & $2,0-6,0$ & 72 \\
\hline $\begin{array}{l}5 . \\
6 .\end{array}$ & $\begin{array}{l}\text { Pernah } \\
\text { Tes HIV } \\
\text { Tahu }\end{array}$ & 50 & 20,6 & 16,1 & $9,0-22,0$ & 20,0 \\
\hline & $\begin{array}{l}\text { Status } \\
\text { (Tes } \\
\text { HIV } \\
\text { dan } \\
\text { terima } \\
\text { hasil) }\end{array}$ & 36 & 88,0 & 72 & $\begin{array}{l}60,0- \\
90,0\end{array}$ & 90,0 \\
\hline
\end{tabular}

Dari tabel 4 dan tabel 5 dapat dilihat prevalensi yang ada di laporan sama dengan prevalensi yang ada di sampel. Prevalensi HIV positif dan IMS di Yogyakarta adalah lebih banyak dibandingkan di Kota Makassar.

\section{Analisis Multivariabel}

Dilakukan analisis dengan variabel independen yaitu Tahu Status dengan variabel dependen yaitu penggunaan kondom konsisten sebulan terakhir di Yogyakarta dan Makassar, dengan variabel outcome yang terlebih dahulu dilakukan pembobotan dengan RDS.

TABEL 6

Asosiasi tahu status HIV dengan penggunaan kondom konsisten pada LSL di Yogyakarta dan Makassar

\begin{tabular}{lrrrrcc}
\hline Kota & \multicolumn{3}{c}{ Crude } & \multicolumn{3}{c}{ Adjusted* } \\
\cline { 2 - 7 } & OR & $95 \% \mathrm{CI}$ & $\mathrm{p}$ & OR & $95 \% \mathrm{CI}$ & $\begin{array}{c}\mathrm{p} \\
\text { value }\end{array}$ \\
\hline Yogyakarta & 3,7 & $1,4-10,1$ & 0,009 & 6,6 & $2,1-20,9$ & 0,002 \\
Makassar & 1,4 & $0,6-3,4$ & 0,4 & 1,6 & $0,6-4,4$ & 0,9 \\
\hline
\end{tabular}

*Adjusted dengan variabel umur, pendidikan, persepsi berisiko, pengetahuan pencegahan, keterjangkauan program/layanan pencegahan, jumlah partner dan pengobatan IMS.

Berdasarkan tabel 6 di Yogyakarta orang yang mengetahui status HIV dirinya odds nya akan lebih 3,7 kali menggunakan kondom secara konsisten dibandingkan orang yang tidak mengetahui status HIVnya dengan crude $O R$ sebesar 3,7 dan 95\% CI 1,4-10,1. Setelah dikontrol variabel umur, pendidikan, persepsi berisiko, pengetahuan pencegahan, keterjangkauan program/layanan pencegahan, jumlah partner dan pengobatan IMS dibandingkan orang yang tidak mengetahui status HIV-nya orang mengetahui status HIV nya odds nya akan lebih 6,6 kali menggunakan kondom secara konsisten dibandingkan LSL yang tidak tahu status HIVnya dengan adjusted OR sebesar 6,6 dan 95\% CI 2,1-20,9.

Hasil analisis di Makassar, odds ratio orang yang mengetahui status HIV dirinya adalah 1,4 dengan 95\% CI o,6-3,4. Setelah dikontrol variabel umur, pendidikan, persepsi berisiko, pengetahuan pencegahan, keterjangkauan program/layanan pencegahan, jumlah partner dan pengobatan IMS dibandingkan orang yang tidak mengetahui status HIV-nya odds ratio orang mengetahui status HIV nya adalah 1,6 dengan 95\% CI o,6-4,4. Hasil tersebut belum bisa mengungkapkan adanya hubungan antara tahu status HIV dengan penggunaan kondom konsisten sebulan terakhir.

\section{E. DISKUSI}

Cakupan tes HIV baik di Yogyakarta maupun di Makassar masih rendah meskipun LSL di Yogyakarta yang pernah melakukan tes HIV lebih tinggi dibandingkan dengan LSL di Makassar. Dari data, baik di Yogyakarta maupun di Makassar, tidak semua LSL yang tes HIV menerima hasil tes. Terjadinya gap antara jumlah yang tes dan yang menerima hasil tes salah satunya karena LSL yang sudah tes tidak mengambil hasil tesnya tersebut, sehingga tidak semua LSL tahu status HIVnya.

Alasan mereka tidak ingin diuji adalah merasa sehat, tidak berisiko, tidak tahu tempat layanan untuk tes HIV dan merasa takut akan konsekuensi hasilnya.

Hal ini sejalan dengan penelitian di Peru ketika membandingkan perbedaan alasan utama peserta LSL yang berisiko rendah tidak melakukan tes HIV yang paling umum adalah alasan takut akan konsekuensi dari hasil tes HIV positif dan selalu menggunakan perlindungan. Sedangkan di antara peserta dalam kelompok berisiko tinggi yang tidak melakukan tes HIV yang paling umum adalah alasan takut akan konsekuensi dari hasil tes HIV positif dan tidak tahu di mana bisa mendapatkan layanan tes HIV ${ }^{[15]}$. 
Sedangkan meskipun sudah melakukan tes HIV, ada diantara mereka yang tidak mengambil hasil tesnya karena takut akan hasil tes tersebut. Menurut Hussain, S.A, et al. (2013) yang melakukan studi kualitatif pada kelompok LSL dalam kasusnya, mereka yang tidak menerima hasil tes adalah mereka yang merasa berisiko tinggi dan takut bila hasil tesnya HIV positif sehingga menyebabkan penundaan untuk mengambil hasil tes atau tidak mengambilnya sama sekali [16].

Beberapa hasil laporan terkait indikator program seperti prevalensi HIV, sifilis, gonore, dan klamidia, serta cakupan tes HIV dan menerima hasil tes HIV berbeda hasil antara RDS dan laporan. RDS dirancang untuk mengestimasi angka yang ada di populasi berdasarkan pengambilan yang dilakukan tidak random atau berdasarkan jejaring. Namun pada laporan jika disesuaikan, angkanya lebih mendekati proporsi crude atau artinya proporsi yang hanya mewakili sampel saja. Sedangkan angka tersebut tidak dapat digunakan untuk mewakili populasi. Jika menganalisis tidak sesuai dengan tekhnik pengambilan sampel nya maka akan terjadi overestimate atau underestimate pada populasi.

Bila dilihat dari nilai proporsi di Yogyakarta, ada kemungkinan bahwa belum tercapainya titik equilibrium dalam pengambilan sampel. Hal ini dapat dilihat dari perbedaan grafik suatu variabel terhadap wave. Sampel yang direkrut di Yogyakarta belum dapat mewakili proporsi di populasi. Sampel yang direkrut di Makassar bila dibandingkan dengan Yogyakarta juga belum dapat mewakili proporsi di populasi karena belum mencapai equilibrium, sehingga nilai proporsi pada sampel berbeda dengan nilai proporsi pada populasi.

Wave yang dianjurkan untuk mencapai titik equilibrium adalah $3^{-} 6$ wave. Titik equilibrium biasanya dicapai di wave ke 6 . Namun apabila belum mencapai titik equilibrium, sebaiknya tetap dilakukan perekrutan meskipun telah melewati batas sampel yang dibutuhkan. Equilibrium adalah keadaan dimana mencapai titik kestabilan yang artinya komposisi berdasarkan sampel tidak berubah atau sama dengan komposisi yang berada di populasi [17].

Di Yogyakarta, meskipun jumlah maksimal wave nya adalah 6 namun untuk setiap seed jumlah wave nya dibawah 6. Sedangkan di Makassar jumlah maksimum wave nya adalah 4 dan rata-rata wave perekrutan pada setiap seed adalah 3. Hal ini dapat membuat kecenderungan data yang dikumpulkan belum mencapai equilibrium yang artinya komposisi dalam sampel belum sama atau berbeda dengan populasi.

Dibawah ini adalah grafik wave terhadap proporsi variabel tes HIV di Yogyakarta dan Makassar;

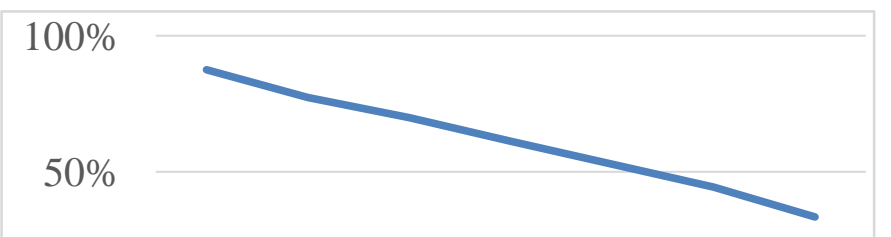

$0 \%$

wave 0 wave 1 wave 2 wave 3 wave 4 wave 5 wave 6 Tes HIV

Gambar 1. LSL yang Tes HIV di Yogyakarta

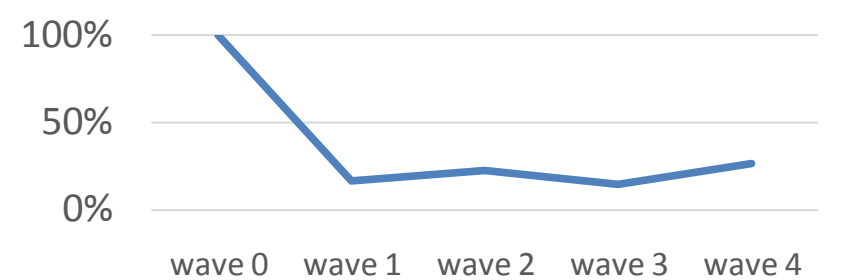

-Tes HIV

Gambar 2. LSL yang Tes HIV di Makassar

Diantara kedua grafik tersebut dapat dilihat di Yogyakarta meskipun banyak LSL yang tahu status HIV dengan semakin bertambah seednya, namun grafiknya cederung menurun atau hanya sedikit LSL di populasi yang tahu status HIVnya. Proporsi di Yogyakarta hanya mewakili sampel dan belum cukup sampel untuk mewakili populasi LSL. Keadaan di Makassar LSL yang direkrut sebagai sampel lebih representatif untuk populasi LSL di Makassar karena grafik cenderung stabil dan hasil proporsi pada sampel dan pada populasi tidak berbeda jauh oleh karena itu proporsi pada sampel dapat dikatakan mewakili proporsi pada populasi LSL.

\section{Penggunaan kondom pada LSL}

LSL yang menggunakan kondom pada seks terakhir dan konsisten menggunakan kondom selama sebulan terakhir dengan hubungan seks bukan komersial maupun seks komersial masih rendah di Yogyakarta. Rendahnya penggunaan kondom pada LSL di Yogyakarta dapat menjadi salah satu kontribusi meningkatnya prevalensi HIV dan IMS di kota tersebut.

Sedangkan di Makassar LSL yang menggunakan kondom pada seks terakhir dan konsisten menggunakan kondom selama sebulan terakhir dengan hubungan seks bukan komersial maupun seks komersial lebih tinggi dibandingkan di Yogyakarta.

Penggunaan kondom secara konsisten yang cukup baik bisa menjadi salah satu kontribusi turunnya prevalensi HIV di Makassar. Berdasarkan data tahun 2009 prevalensi HIV sebesar 3\% dan tahun 2013 sebesar $1 \%$ [2].

Berdasarkan hasil dari kedua kota tersebut, sejalan dengan penelitian yang dilakukan Smith, DK, et al [18]. Di antara LSL melaporkan hubungan seks anal dengan pasangan pria HIV-positif, ditemukan efektivitas $70 \%$ dengan penggunaan kondom secara konsisten (dibandingkan dengan tidak pernah menggunakan). Tidak ada perlindungan yang signifikan ketika membandingkan kadang-kadang menggunakan kondom dengan yang tidak pernah menggunakan kondom. Alasan yang sering disebutkan di antara LSL untuk penggunaan non-kondom adalah ketidaksukaan kondom, kenikmatan kulit-ke-kulit, perasaan dan kekhawatiran tentang kesenangan berkurang [19]. Faktor interpersonal terjadi antara pasangan seksual yang memprediksi praktik seksual, seperti status hubungan, masalah keintiman, dan komunikasi interpersonal.

Ketidaktersediaan atau kerusakan kondom juga telah disebut-sebut sebagai hambatan untuk penggunaan kondom [19]. Pengetahuan ini dapat mempengaruhi persepsi individu risiko HIV dan mempengaruhi perilaku penggunaan kondom [20]. 


\section{Analisis Multivariabel}

Hasil di Yogyakarta menunjukkan adanya pengaruh yang positif antara tahu status HIV dengan penggunaan kondom konsisten sebulan terakhir.

Hal ini sesuai dengan penelitian yang dilakukan [21] bahwa peningkatan kesadaran di antara LSL yang mengetahui status HIVnya dan variasi risiko yang berpotensi membuat peran dalam seks merupakan faktor penting dalam keputusan tentang apakah akan menggunakan kondom. LSL yang menjadi pasangan reseptif lebih mudah tertular HIV dibandingkan dengan LSL yang menjadi pasangan insertif.

Seroadaptasi telah digunakan untuk berbagai praktek pengurangan dampak buruk seksual berdasarkan pengetahuan status HIV dirinya dan mitra serostatus ${ }^{[10],}$. Melihat tingginya prevalensi kejadian HIV di Yogyakarta responden yang konsisten dalam menggunakan kondom adalah responden yang sudah mengetahui status HIVnya. Wolitski, et al. [22] menemukan bahwa LSL dalam hubungan biasa merasa bertanggung jawab untuk melindungi kesehatan pasangan mereka dengan mempraktekkan seks yang lebih aman, yang mungkin mencakup mitra non-primer.

Namun, penelitian lain mengaitkan tingkat tinggi terhadap keintiman dalam hubungan seksual primer dengan perilaku pengambilan risiko seperti tidak menggunakan kondom pada pasangan yang memiliki serostatus yang sama [23].

Hasil yang berbeda di Makassar, hasil tersebut belum bisa mengungkapkan adanya hubungan antara tahu status HIV dengan penggunaan kondom konsisten sebulan terakhir. Hal ini dapat dikarenakan masih sedikitnya responden di Makassar yang sudah tes HIV dan tahu status HIVnya.

\section{F. SIMPULAN DAN SARAN}

Berdasarkan analisis yang telah dilakukan dapat disimpulkan sebagai berikut:

1. Hasil analisis multivariat di Kota Yogyakarta menunjukkan adanya pengaruh yang positif antara tahu status HIV dengan penggunaan kondom konsisten setelah dikontrol variabel umur, pendidikan, persepsi berisiko, pengetahuan pencegahan, keterjangkauan program/layanan pencegahan, jumlah partner dan pengobatan IMS.

2. Hasil analisis mutivariat di Kota Makassar tersebut belum bisa mengungkapkan adanya pengaruh antara tahu status HIV dengan penggunaan kondom konsisten.

3. Terdapat perbedaan hasil antara hasil RDS penelitian ini dengan laporan STBP karena penelitian ini menggunakan analisis dengan memperhatikan metode pengambilan sampelnya.

Kemudian tim peneliti memberikan beberapa saran senagai berikut:

1. Dalam menyajikan data dengan perekrutan sampel respondent driven sampling, diharapkan untuk menggunakan metode RDS dalam melakukan analisis datanya.

2. Mengevaluasi kembali perhitungan sampel minimal untuk perekrutan RDS.

3. Meminimalisasi bias yang dapat terjadi akibat socio norm dengan cara melakukan pendekatan yang lebih baik agar responden terbuka untuk menjawab jujur dari setiap pertanyaan yang ada pada kuesioner

4. Meningkatkan cakupan tes HIV pada LSL dengan cara menjemput bola atau menjangkau LSL yang tidak datang ke tempat pelayanan.

5. Meningkatkan akses dan layanan komperhensif HIV terutama untuk akses pelayanan tes HIV secara regular dan berkala

6. Meningkatkan pengetahuan untuk testing HIV agar LSL dapat mengetahui status HIVnya sehingga dapat mengurangi perilaku berisiko HIV atau mencegah terjadinya penularan HIV dan pengobatan HIV serta IMS.

7. Meningkatkan promosi tes HIV dan penggunaan kondom pada kelompok LSL agar LSL tahu status dapat menggunakan kondom secara konsisten.

8. Untuk penelitian selanjutnya agar lebih berhati-hati dalam pengambilan sampel dan memperbanyak wave agar bisa di generalisasi di populasi.

\section{UCAPAN TERIMA KASIH}

Tim penulis mengucapkan terima kasih kepada UM Mataram yang telah menyetujui paper ini untuk diterbitkan.

\section{DAFTAR RUJUKAN}

[1] UNAIDS. (2014). The Gap Report. Diakses pada tanggal 29 desember 2014 pukul 05.33

[2] Ditjen PP dan PL, Kementrian Kesehatan RI. (2013). LaporanPemantauan Prevalensi HIV melalui Surveilans Terpadu Biologi Dan Perilaku (STBP).

[3] Mattapalli JJ, Douek DC, Bukit B, et al. (2005). Infeksi besar dan kehilangan memorisel CD4 $+T$ di beberapa jaringan selama infeksi SIV akut. Nature. 2005 April 28, 434 (7037): 1093-7.

[4] Mowat AM, Viney JL. (1997). Dasar anatomi kekebalan usus. Ulasan April, 156: 145-66.

[5] Zuckerman RA, Whittington WLH, Celum CL, et al. (2004). Konsentrasi yang lebih tinggi dari HIV RNA di sekresi mukosa dubur dibandingkan dalam darah dan plasma seminal, antara laki-laki yang berhubungan seks dengan laki-laki, independen ART. Journal of Infectious Diseases. 2004 Juli 1, 190 (1): 15661.

[6] Australian Federation of AIDS Organisation. (2012). HIV testing in among gay men and other men who have sex with men. Diakses pada tanggal 24 November 2014.

[7] Hessol $\mathrm{N}$ et al., (1989). Condom history, effectiveness and testing. Diakses pada tanggal 20 Desember 2014

[8] UNAIDS. (2004). Making condoms work for HIV prevention. Diakses pada tanggal 22 November 2014

[9] McConnell, J. Jeff, Bragg, Larry, Shiboski, Stephen , M. Grant, Robert. (2009). Sexual Seroadaptation: Lessons for Prevention and Sex Research from a Cohort of HIV-Positive Men Who Have Sex with Men. Published: January 21, 2010 DOI: 10.1371/journal.pone.0008831

[10] Le Talec J, Jablonsky O. (2012). Seroadaptation bukan serosorting: konsep yang lebih luas dan model proses yang lebih tepat. Diakses 17 Februari 2012.

[11] Mlongo, Sakhile, et.al. (2013) . Factors Associated with Not Testing For HIV and Consistent Condom Use among Men in Soweto, South Africa. Diakses pada tanggal 24 November 2014.

[12] Willi McFarland, Yea-Hung Chen, H Fisher Raymond, et all. (2008). Seroadaptation HIV antar individu, dalam perilaku seksual, dan dengan episode seksual, pria yang berhubungan 
seks dengan laki-laki, San Francisco. Diakses pada tanggal 26 November 2014.

[13] Kalichman, S. C., Nachimson, D., Cherry, C., \& Williams, E. (1998). AIDS treatment advances and behavioral prevention setbacks: Preliminary assessment of reduced perceived threat of HIV-AIDS. Health Psychology, 17(6), 546-550. Diakses pada tanggal 2 Desember 2014.

[14] Morris M, Kretzschmar M. (1997). Concurrent partnerships and the spread of HIV. Diakses pada tanggal 2 Desember 2014.

[15] M Blass, Magally, Isaac E. Alva, et al., (2011). Perilaku Risiko dan Alasan tidak Mendapatkan Diuji untuk HIV di kalangan laki-laki yang Berhubungan Seks dengan Pria: Sebuah Survey Online di Peru. Diakses pada tanggal 2 Desember 2014.

[16] Hussain, S.A. (2013). Activity Pattern, Behavioural Activity and Interspecific Interaction of Smooth-Coated Otter (Lutrogale perspicillata) in National Chambal Sanctuary, India IUCN Otter Spec. Group Bull. 30 (1): 5 - 17. Diakses pada tanggal 2 Desember 2014.

[17] Heckathorn, Douglas D. 2002." Respondent-Driven Sampling II: Deriving Valid Population Estimates from Chain-Referral Samples of Hidden Populations." Social Problems. Diakses pada tanggal 3 Desember 2014

[18] Smith, Dawn K., Herbs, Jeffrey, et al.. (2014). Condom Effectiveness for HIV prevention by Consistency of use among Men Sex with Men in US. Diakses pada tanggal 5 Desember 2014.

[19] Carballo-Diéguez A,Bauermeister JA. (2004). "Barebacking": Intentional condomless anal sex in HIV-risk contexts Reasons for and against it. Journal of Homosexuality. 2004;47(1):1-16

[20] Parsons JT, Schrimshaw EW, Bimbi DS, Wolitiski RJ, Gomez CA, Halkitis PN. Consistent, inconsistent, and non-disclosure to casual sexual partners among HIV-seropositve gay and bisexual men. AIDS. 2005;19:S87-97. [PubMed]

[21] Detels R, English P, Visscher BR, Jacobsen L, Kingsley LA, Chmiel JS, Dudley JP, Eldred LJ, Ginzburg HM. Seroconversion, sexual activity, and condom use among 2915 HIV seronegative men followed for up to 2 years. Journal of Acquired Immune Deficiency Syndromes. 1989;2(1):77-83. [PubMed]

[22] Wolitski RJ, Parsons JT, Gomez CA. Prevention with HIVSeropositive men who have sex with men. Lessons from the Seropositive Urban Men's Study (SUMS) and the Seropositive Urban Men's Intervention Trial (SUMIT) Journal of Acquired Immune Deficiency Syndromes. 2004;37(suppl 2):S101-S108. [PubMed]

[23] Theodore PS, Durán REF, Antoni MH, Fernandez MI. Intimacy and sexual behavior among HIV-positive men who have sex with men in primary relationships. AIDS and Behavior. 2004;8(3):321-31. [PubMed]

\section{PROFIL PENULIS UTAMA}

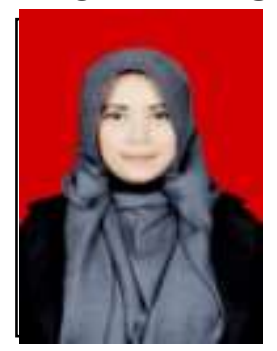

Penulis lahir di Cirebon, 03 Februari 1990. Setelah lulus SMA melanjutkan kuliah DIII Kebidanan di POLTEKKES KEMENKES BANDUNG PWJ BOGOR pada tahun 2008. Lulus sebagai bidan di tahun 2011, penulis melanjutkan kuliah DIV Kebidanan di STIKES Bhakti Pertiwi Indonesia sambil bekerja sebagai tenaga lepas di Puskesmas Kota Bogor selama 3 bulan kemudian menjadi asisten bidan di bidan praktek swasta. Penulis melanjutkan kuliah DIV dan S1 Ilmu Kesehatan Masyarakat peminatan Kesehatan Keselamatan Kerja di STIKES Mitra Ria Husada. Setelah lulus DIV Kebidanan Tahun 2012 Penulis bergabung menjadi bagian dari kampus Akademi Kebidanan Prima Husada Bogor dan melanjutkan kuliah Magister Ilmu Kesehatan Masyarakat Peminatan Kesehatan Reproduksi di Universitas Indonesia pada tahun 2013 dan lulus di tahun 2015. Setelah menikah, penulis yang semula berdomisili dan bekerja di Kota Bogor, pindah ke Kota Semarang mengikuti suami. Saat ini penulis bekerja di Akademi Kesehatan Asih Husada Kota Semarang. 